\title{
Design models and "attention" to the topography of the places in the sixteenth strongholds of Sardinia: the use of the tenaille
} Andrea Pirinu

Department of Civil - Environmental Engineering and Architecture, University of Cagliari, Italy, apirinu@unica.it

\begin{abstract}
The present contribution proposes, through some representative digital models and graphical schemes, some technical aspect that characterizes the work of Jacopo and Giorgio Paleari Fratino, military engineers in the service of Philip II of Spain in the second half of the sixteenth-century. Matrices and geometric models directly extracted from the military treatises, in particular from the text Della fortificatione della città wrote by G. Maggi and J.F. Castriotto and published in Venice in 1564, are skillfully adapted to the topography of the places and lead plastic solutions that optimize resources and respect of architectural design of modern fortifications. A research set on the graphical analysis of archival documents, examination of military treatises, survey of the existing structures of Sardinia and a comparison with the works realized in the Spanish strongholds of the Mediterranean area that confirms and emphasizes the phrase, attributed to Paleari and reported in historical archive documents, that reiterates to acompagnar las obras con la naturaleza del sitio (execute the works according to the topography of the places).
\end{abstract}

Keywords: Paleari, sixteenth-century fortifications, Sardinia, geometric matrices.

\section{The work of Paleari in Sardinia}

The activity of the Jacopo and Giorgio Paleari takes place starting from 1558 and until 1589 in the service of the Crown of Spain and is characterized by high quality projects and works that change the urban landscape of the most important strongholds of the Kingdom.

In 1563 Jacopo El fratin is sent from Milan to Sardinia, when is employed as a substitute of the engineer Gianmaria Olgiati, who died in 1558. His visit change projects and works in progress on the construction sites of Cagliari and Alghero through, a design that follows the modern project techniques and a declared use of the military treatises (Casu 2004).

Obtained the title of engineer in 1565, while he served in the spanish fort of La Goletta of Tunis, and the title of ordinary captain of infantry in 1573 is in charge of Island strongholds until
1578, joined in the direction of the works by his brother Giorgio, author of several proposals for the expansion of the traça of El fratin.

The intervention of Paleari, necessary especially after the fall of the Goletta of Tunis (1574) and decisive to strengthen the defenses of Sardinia, modify the works designed by Rocco Capellino from Cremona, author of the designs for the strongholds of Cagliari, Oristano, Alghero and Sassari and employed in the Island starting from 1552 and until 1572, when was replaced by Giorgio Paleari.

The two brothers are mainly involved in Cagliari and Alghero, considered the most important strongholds, with design solutions that use, in addition to a precise respect of the correspondences between the artillery, some models proposed by the military treatises, 
adapted to the existing buildings and strctures and to the topography of the area.

The catalog of the solutions adopted is composed of pentagonal bastions, folded back curtains, salient, tenaille and reuse of existing structures, organized and functional to the new defense system. Among these stylisticconstructive compositions appears the use of the tenaille that, as well as the succession of salient, allows to realize a design that follow the morphological characteristics of the site.

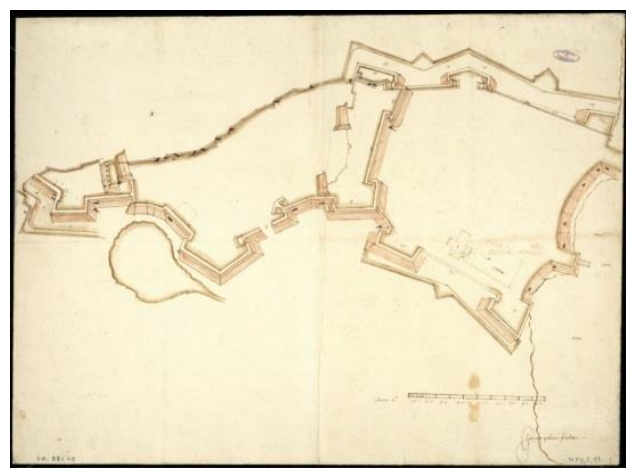

Fig. 1- Giorgio Paleari's drawing of the stronghold of Cagliari (España. Ministerio de Cultura. Archivo General de Simancas, MPD, 08,019. Published in Pirinu 2013).

\section{The tenaille in military treaties and in the works of the engineers of the sixteenth century}

The design solution is developed by Pedro Luis Escrivà, a spanish military engineer in the service of Carlos $V$ and used by the most important engineers of sixteenth century.

His graphical-design process (Fig.3) allows a complete coverage of the defensive line, as shown in the fort of St. Elmo in Naples, designed in the 1537 by the same engineer for the King of Spain; this solution, aimed at the design of an isolated fortress, starts from a basic shape like the rectangle. The use of the tenaille may also be directed at the completion of existing works and in particular in the case where it is required a growth of the defensive line along a given direction. The model developed by Escrivà find many applications in the work of military engineers (and will also become the place of the comparisons and contrasts between prominent personalities such as Giovanni Battista Antonelli, Vespasiano Gonzaga and Jacopo Paleari) and is inserted between the design solution suggested in the treaty Della fortifications of the city, written by Girolamo Maggi and the Captain Castriotto and published in Venice in 1564. This solution, in 1580, will be plastically adapted to the topography of the places by Jacopo to design the formal solution of the fortress of San Felipe in Setubal (Portugal), of the fortress of Santa Barbara in Alicante (Spain) and, in Sardinia (Italy), of the tenaille of San Pancrazio in Cagliari and proposed by Giorgio Paleari to advance the front of fortification of Alghero and draw the fort of San Giuliano not far from the same city. In Setubal, El fratin, will define the final solution with two tenailles combined with a half bastion and a salient (Fig.5), in Alicante will change the design of the fortress pulling back the existing line and setting the tracking on the existing medieval towers (Figg.6-7) and in Cagliari will expand the works carried out by Rocco Capellino and represented by a solution that shows the reuse of the work built by the Viceroy Joan Dusay built in the early sixteenth century.

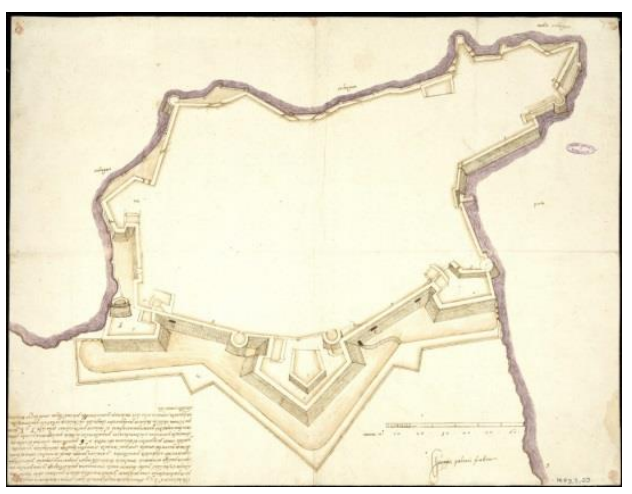

Fig. 2- Giorgio Paleari's drawing of the the stronghold of Alghero (España. Ministerio de Cultura. Archivo General de Simancas, MPD,08,020. Published in Pirinu 2013).

Most of Giorgio Paleari's project proposals have no concrete outcome but are very interesting about the technical choices adopted. The advance of the front of Alghero has the objective 
of reaching the share of the collina della giustizia, located in front of the bastion of Sperone, designed by Capellino and considered useless according to the opinion of Fratino.

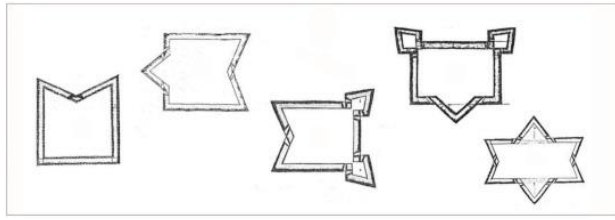

Fig. 3- Development of the tenaille (da Akacha 1999).

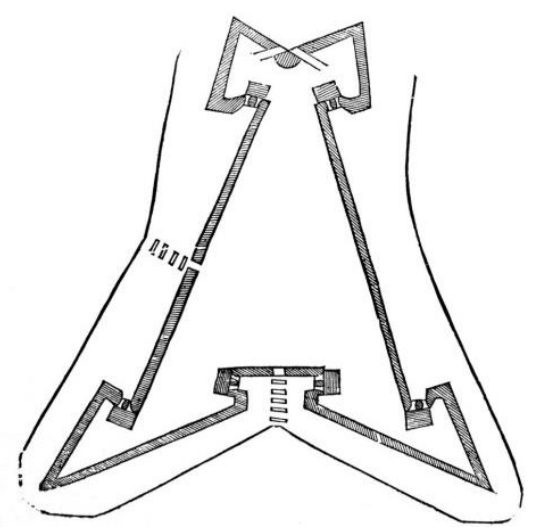

Fig. 4- fortress model obtained with a tenaille and two half bastions connected by two straight curtains (fonte: Della fortificatione delle città).

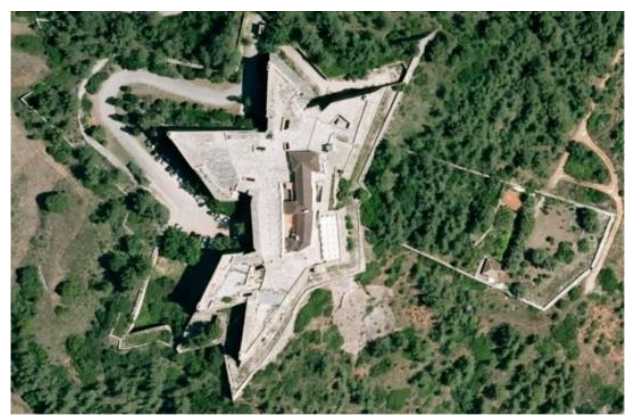

Fig. 5- Fortress of San Felipe in Setubal (aeral view from http://maps.google.it)

The analysis of the projects shows a graphic construction coordinated by pre-existing element (such as the medieval towers) and geometric matrices, that determine the shape and the size of the new line of defense. The project for the fortress of San Giuliano, not far from the city, shows a rigorous application of the Treaty of Maggi and Castriotto (Fig.4) and a particular focus about the morphology of the area, as shown by the comparison between the project design and a recent aerophotogrammetric survey (fig.11).

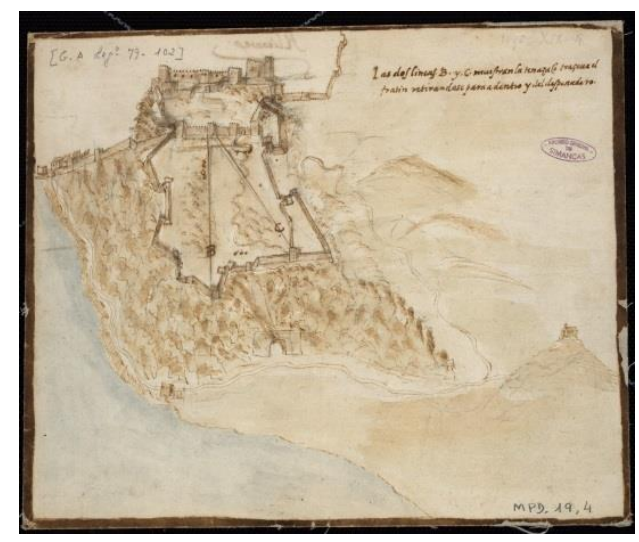

Fig. 6- Vespasiano Gonzaga's drawing that shows the indication of El Fratin for the fortress of Santa Barbara (España. Ministerio de Cultura. AGS, MPD, 19,004. Published in Pirinu 2013).

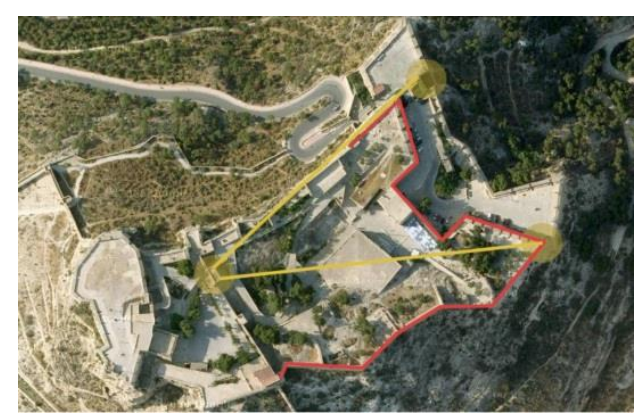

Fig. 7- Fortress of Santa Barbara in Alicante: identification of project references. Graphic elaboration (fonte http://maps.google.it).

\subsection{The front of Alghero: Giorgio Paleari's design of the tenaille}

The archival records that describes the interventions designed to Alghero in the second half of the sixteenth century is particularly interesting and characterized by a remarkable graphical-descriptive quality. This is due to the ability in survey and design that uses Giorgio Paleari in 1573 (Fig.8) to show the modifications indicated ten years earlier by his brother Jacopo, 
its proposals, and highlight with designs specifically "wrong", the uselessness of the works attributed to the technician who preceded him, and to design the project of the fortress to be built on the hill of San Giuliano.

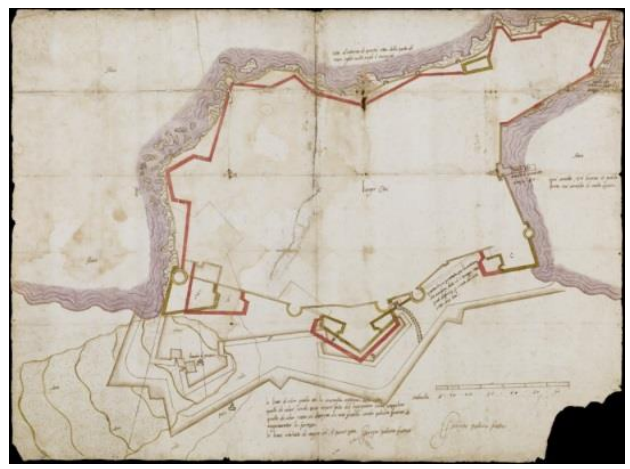

Fig. 8- Giorgio Paleari's drawing (larger Città, s.d., CRSAB, PV, Cart, g.27/9. Published in Pirinu 2013).

The proposal for the advancement of the front proposed by the engineer is represented by a tenaille connected by a straight curtain to the bastion of Montalbano; these models are coordinated and, as suggested by graphical analysis, based on the use of two key points that determine size and shape of the tenaille and the modification of the bastion of Montalbano (in expansion than the solution of Jacopo and the works realized by Capellino).

Therefore, it can be seen as the "dotted" traces indicated in the drawing, converge in a first point of reference represented by the intersection between the curtain and the flank of the bulwark that Jacopo Paleari positioned between the bulwark of Sperone and the bastion of San Giacomo.

The size of the faces of Montalbano, defined along the lines 1-5 and 5-6, and the necessity of defend the city gate, identify the graphicaldesign parameters 5-7 that, supported by the axis 4-5 (that defined the top advanced of the front) and by the openings of the compass equal to $\mathrm{R} 1=\mathrm{R} 2$ complete the design of the system tenaille - bulwark (Fig. 9).

The new front, concluded by a ditch with counterscarp and covered way, shows, in conclusion, a defense of the tenaille entrusted to the artillery present in the bulwark present between the Sperone and the San Giacomo and to the gunboats positioned in the "traitors" flank of Montalbano whose faces will themselves protected by the crossfire of the guns of the bastion of La Maddalena and by the artillery positioned in the "traitors" flank of the tenaille.

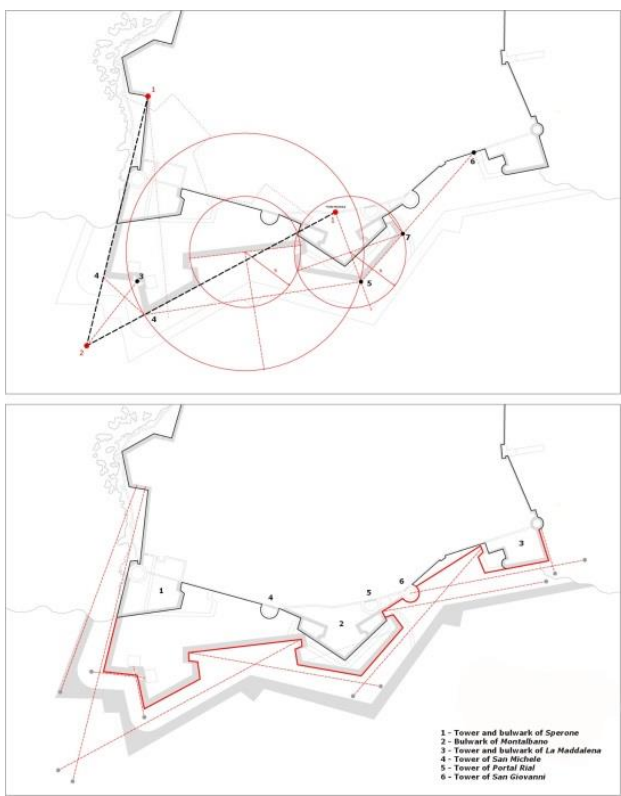

Fig. 9- Giorgio Paleari's design: identification of

Giorgio Paleari's design solution for the fortress of San Giuliano (fig. 10) is defined through the combination of two half bastions connected with a succession of salient and a tenaille, where he uses one of the schemes proposed by the Treaty of Girolamo Maggi and J. F. Castriotto.

The two half bastions are placed on the east end of the hill that, mostly flat, has a slight irregularity elevation that produces a slight height difference northeast, where the design of the project indicates the pit (fossa) near the ancient well (pozo antiguo)

The report that integrates the drawing describes the cost for the construction of the works, the architectural features of the works themselves, the positioning of the fortified perimeter and the ditch, where are precisely indicated the morphological characteristics of the site and the 
pre-existing building object of a detailed survey carried out by the engineer togheter Juan Bautista Reyna. The document contains beyond the usual orientation with the cardinal axes, the measurement scale in canes and some indications of the project and more precisely: "Li duoi baluardi et cortina signati A anderano halti alla ordinaria altez.a il Restante della Circonferentia bastera che si alzi suolo fuori di scala che douendo esser' de muraglia p. causa di tenerlo longo tempo et p. metter dentro meza cana di terra de altez.a almeno et p. che il fosso andera fuor nela ridota costera Circha schudi 30 millia".

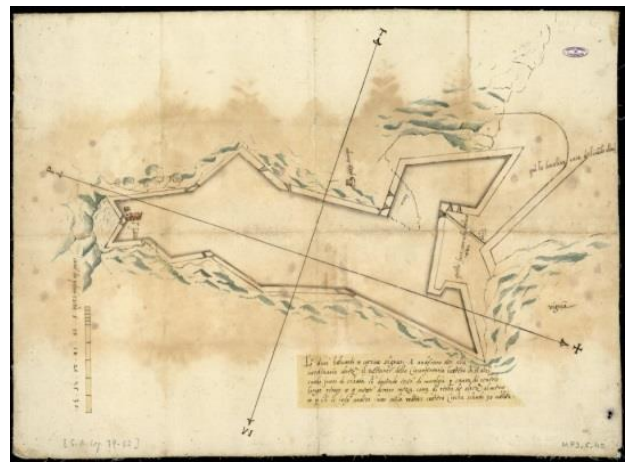

Fig. 10- Design for fortress of San Giuliano. España. Ministerio de Educación, Cultura y Deporte. Archivo General de Simancas, MPD_05_040. Published in Pirinu 2013).

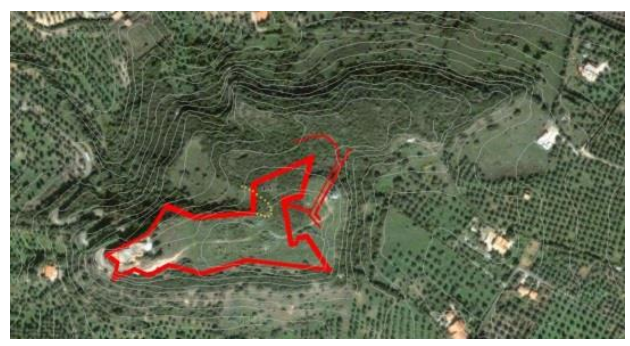

Fig. 11- Overlay mapping between the design (with a measurement scale that use roman palms) and a recent aerophotogrammetric survey.

The measurement scale is indicated in canes composed of 12 palms that we can assume may be roman palms (equal to $22,23 \mathrm{~cm}$ ) used for sure by Giorgio in the graphical representation of the Santa Chiara's curtain in Cagliari.
This possibility is supported by the exclusion of the use of canes constituted by 12 palms of 26.2 $\mathrm{cm}$, not compatible with the design in relation with the morphology of the site.

The construction of the bastions is prescribed by the "ordinary height" that, in the treaty of Maggi and Castriotto assumes precise formal characteristics. In particular the Book II, Cap. I, Delle scarpe delle muraglie, reported "L'ordinaria scarpa che si dà alle muraglie, si è, in ogni cinque braccia d'altezza, un piede, e questo fino al cordone. Dal cordone in sù alcuni non vogliono che si dia pùto di scarpa. ad altri piace indistintamente ch'ella si dia. l'opinion di questi ultimi è degna d'esser abbracciata, perche, come habbiamo detto un'altra volta, la scarpa dà fortezza al muro, \& il perpendicolo l'aiuta a rovinare. Darassi adunque alla muraglia dal cordone in su un mezo piede di scarpa, ò qualche poco di più ", and Capitan Castriotto in the Book I, Cap. XI, Delle misure di tutti i membri della Fortificatione, e delle parti di quelli, suggests the most appropriate measures for the design of the bastion. The wall of the bastion (Castriotto): "la vuole alta dal fondo del fosso fino al cordone piedi 24 . e piedi 8 , dal cordone alla cima, che con un piede della grossezza del cordone è in tutto dal lato di fuori piedi 33. e di dentro 36, per cagione del colmo più alto che non è di fuori".

The ordinary height of the bastions becomes, in accordance with the treaty and the choice of using a foot size of $33 \mathrm{~cm}$ : from the bottom of the ditch until the cord equal to 24 feet $(7,92 \mathrm{~m})$, from cord to the top equal to 8 feet $(2,64 \mathrm{~m}$ - the measure of the parapet) - and with the cord one foot thick $(33 \mathrm{~cm})$ result an external total height of 33 feet $(10,89 \mathrm{~m})$ an internal total height of 33 feet $(11,88 \mathrm{~m})$. In the Book I, Cap. XI Girolamo Maggi also riported that the Capitan Castriotto "nel suo discorso generale vuole che le controscarpe siano alte al pari de' i cordoni; \& anche due piedi più alte di quelli " it means that the height of the counterscarp must be the same of the height of the cord.

The abilities that Giorgio Paleari demonstrates executing the survey of the project area, together with the indications of the Treaty, allows to the 
definition of a virtual model of the fortress (fig.13).
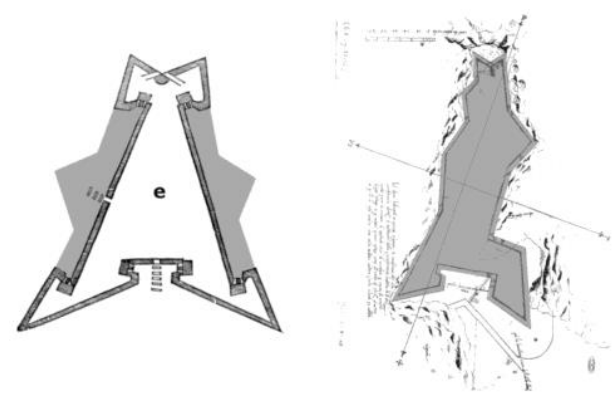

Fig. 12- Design process

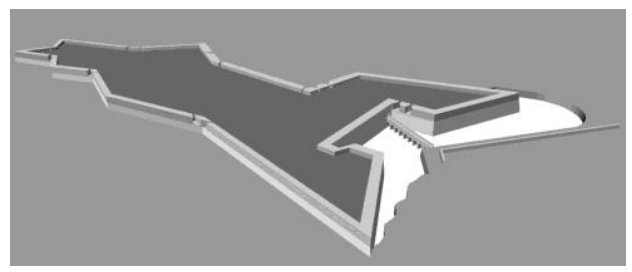

Fig. 13- Fortress of San Giuliano: digital model of Giorgio Paleari’s design.

\subsection{San Pancrazio's tenaille in Cagliari}

Rocco Capellino in 1552 designed the new fortification of Cagliari, that, set in the medieval towers of the Leone and of the Elefante, defines in the north, the position of the tenaille (fig.14).

The project requires a progress aimed at achieving a share (and location) necessary to ensure the defense of the north, a sector that will be the subject of growth until the eighteenth century, in the Savoy period.

The tenaille is connected to a perimeter defense, set in the Aragonese period, that is equipped with the bulwark built by the viceroy Joan Dusay in early sixteenth century. The work, directed towards the hill of San Pancrazio, is modeled on the west by the shooting of the gunboat positioned along the curtain of San Guglielmo and to the east, follows, stepping back, the morphology of the rock that controls the cliff that separates the district of Castello from the fourteenth-century settlement of Villanova. In 1558 the engineer starts the work and in the 1563 (when Jacopo Paleari is visiting the strongholds of Sardinia) complete them with a different shape from the one chosen during the design phase. This choice is due to the reuse of the "bulwark Dusay" as gunboat to protect the tenaille itself. The intervention of Paleari (period 1573-1578) change the works executed by Rocco Capellino: determines an expansion of the tenaille in westerly and easterly direction where the perimeter moves and reaches the extreme edge of the rock (fig.17) and the "bulwark Dusay" is raised to function as a knight to protect the entire defensive sector, as shown in the Giorgio Paleari's drawing performed in the summer of 1578 (fig.15).

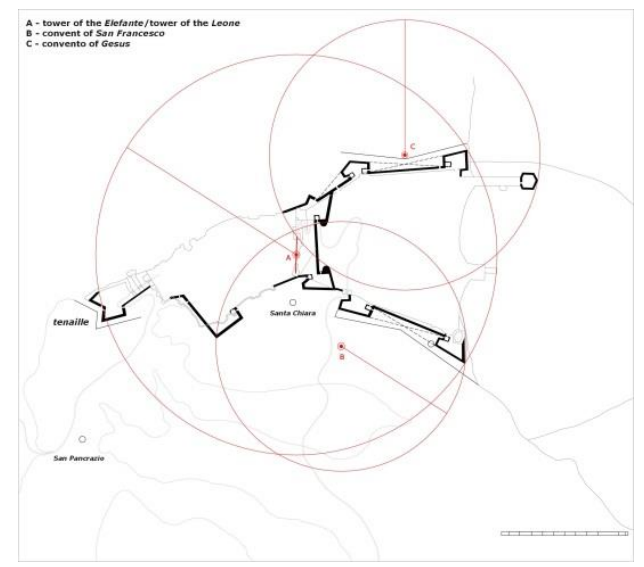

Fig. 14- project references in Rocco Capellino's design.

\section{Conclusions}

The analysis of the works realized by the engineers who operated in the strongholds of Sardinia in the period 1552-1578 showed a mastery of modern surveying and project techniques of the architecture and the city.

This condition has allowed to the construction of military architecture characterized by a correct maneuvering space, a respect of the correspondences between adjacent bastions and an optimal use of morphological conditions of the places in order to optimize financial resources and quality of the project.

One of the models used for the resolution of design problems is the tenaille, optimal choice to advance the line of defense along a preferred direction or compose a "drawing" of a fortress 
isolated using multiple functional elements combinated with each other.

The study of the work of Paleari's brother has conduced to the creation of some graphical models that describe an application of the tenaille as shown in military treatises and the use of geometric matrices to control the whole design process.

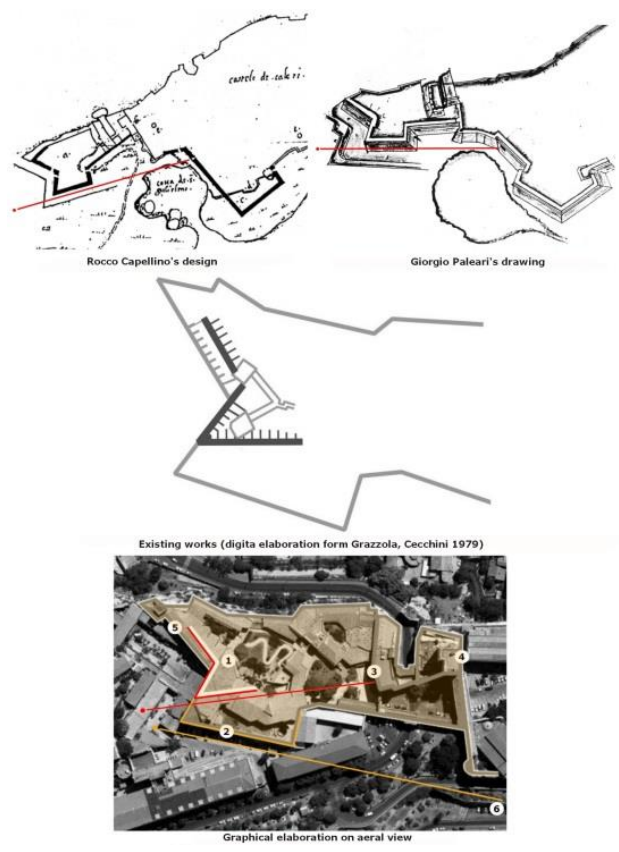

Fig. 15- Comparison between graphical documentation archival and survey of existing structures: 1- Capellino's works, 2-5 Paleari's works, 3- Dusay's bulwark, 4- tower of San
Pancrazio, 6- trajectory of gunboat positioned along the curtain of San Guglielmo.

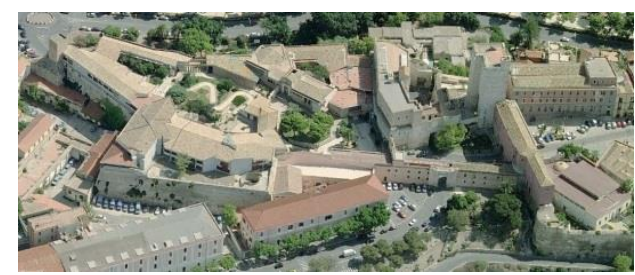

Fig. 16- Today's view of the area of San Pancrazio (fonte: http://maps.google.it).

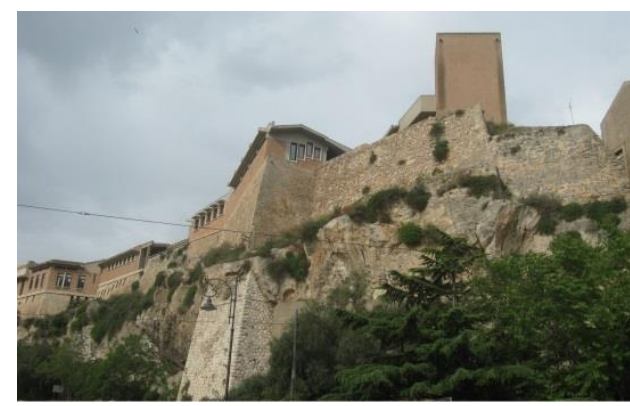

Fig. 17-Cittadella dei musei: the east front.

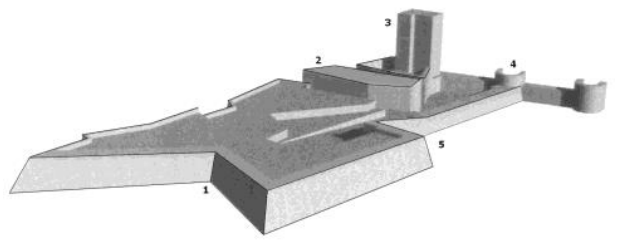

Fig. 18- 3D model of San Pancrazio's sector: 1tenaille, 2- Dusay's bulwark, 3- tower of San Pancrazio, 4- medieval tower, 5- position of new city's gate (digital elaboration from Casu 2004).

\section{References}

Akacha J., (1999). I cristiani di Allah: architetti e ingegneri militari rinnegati al servizio dell'Impero ottomano specialmente negli stati barbareschi del Nord Africa durante il XVI secolo, in Architetti e ingegneri militari italiani all'estero dal XV al XVIII secolo (a cura di M. Viganò), pp.55-91.

Cámara Muñoz A., (1998). Fortificación y ciudad en los reinos de Felipe II. Madrid.

Cámara Muñoz A., (2004). Giovanni Battista Antonelli e la definizione professionale dell'ingegnere nel Rinascimento spagnolo. in atti del Convegno internazionale di studi Omaggio agli Antonelli. Gatteo, 3-5 ottobre 2003. Forum Edizioni. Udine.

Casu S., (2004). La torre e la tenaglia di S.Pancrazio. in atti (a cura di Federica Ribera) del convegno internazionale dal titolo Luce tra le rocce. Salerno 29-30 Aprile 2004. pp. 70-77.

Cardone V., (2001). Pedro Luis Escrivà. Ingegnere militare del Regno di Napoli. CUES. Salerno. 
Gazzola P., Cecchini L., (1979). La cittadella museale della Sardegna in Cagliari. Università degli Studi di Cagliari.

Hogg J., (1982). Storia delle fortificazioni. Novara.

Maggi G., Castriotto J., (1564). Della fortificazione delle città. Venezia. Edizione consultata Ristampa anastatica. 1982. Padova.

Pirinu A., (2013). Il disegno dei baluardi cinquecenteschi nell'opera dei fratelli Paleari. Le piazzeforti della Sardegna. Ed. All'insegna del Giglio. Firenze.

Sari G., (1988). La piazza fortificata di Alghero. Edizioni del sole. Alghero.

Viganò M., (2004). El fratin mi yngeniero, I Paleari Fratino da Morcote ingegneri militari ticinesi in Spagna (XVI-XVII secolo). Istituto Grafico Casagrande SA. Bellinzona. 